Grzegorz Biesok

Jolanta Wyród-Wróbel

University of Bielsko-Biata

\title{
PROACTIVE PURCHASE BEHAVIOUR AND THEIR RELATIONS IN SIMPLE SATISFACTION MODEL
}

The purpose of the paper was to verify how proactive shopping behaviours, as declared by the respondents, affect the relationship between expectations, perceived quality and customer satisfaction within a simple satisfaction model. The subject of research was supermarket customers. The authors of the article assumed ten proactive shopping behaviours and then built and verified a satisfaction model in the groups of respondents declaring, or not declaring, the given behaviour.

The main conclusions resulting from the analysis is that satisfaction with purchases is more determined by the perceived quality in the case of customers who declare frequent purchases of products that improve the standard of living, consistency in purchasing perceived products and rapidity of purchasing decisions.

Keywords: consumer research, proactive consumer behaviour, satisfaction model, structural equation modelling (SEM)

JEL Codes: M310, L810

\section{Introduction}

A buyer is not left alone in a purchase decision process. In addition to the influence of family or friends, buyers are influenced by marketing communication which uses various instruments to attract their attention. It depends on the buyer how much information $\mathrm{s} / \mathrm{he}$ receives, how much $\mathrm{s} / \mathrm{he}$ absorbs from marketing communications or how much $\mathrm{s} /$ he engages in the preparation of the offer (e.g. prosumption), before making a purchase decision.

Readiness to acquire the knowledge on a given topic, finding information, taking active steps to adapt the environment to own needs are some examples of proactive behaviours mentioned in the literature in the context of work or career $(\mathrm{Ch} . \mathrm{H}$. Wu and S. K. Parker ${ }^{1}$, M. L. Mallin et al. ${ }^{2}$, Ling at al. ${ }^{3}$, Ismail et al. ${ }^{4}$, Claes and Loo $^{5}$ ). In this respect, the buyer can also be proactive when s/he takes actions, such as: searching

\footnotetext{
${ }^{1}$ Ch. H. Wu and S. K. Parker: Thinking and acting in anticipation: A review of research on proactive behavior. Advances in Psychological Science, 21(4)/2013, p. 679-700.

${ }^{2}$ M. L. Mallin, Ch. B. Ragland and T. A. Finkle: The proactive behavior of younger salespeople: Antecedents and outcomes. Journal of Marketing Channels, 21/2014, p. 268-278.

${ }^{3}$ N-P. Ling, N. F. A. Bandar, F. A. Halim and A. L. Muda: Proactive behaviour as a mediator in the relationship between quality of work life and career success. International Journal of Business and Society, 18 S4/2017, p. 701-709.

${ }^{4}$ A. Ismail, W.A.W.M Nowalid and R.A. Bakar: Proactive behaviour as a mediator of the relationship between career management and career satisfaction. Jurnal Pengurusan (UKM Journal of Management), 48/2016, p. 99-110.

${ }^{5}$ R. Claes and K. V. Loo: Relationships of proactive behaviour with job-related affective well-being and anticipated retirement age: an exploration among older employees in Belgium. European Journal of Ageing, $8(4) / 2011$, p. 233-241.
} 
for offers, analysing technical data, comparing, checking rankings, testing products, visiting various points of sale, etc. The scope of proactivity of the buyers may be different, change in time and adapt to the certain circumstances.

\section{Literature review}

The decisions of clients and their behaviours are determined by numerous factors described extensively in various publications by such authors as M. MiczyńskaKowalska ${ }^{6}$, A. Falkowski and T. Tyszka ${ }^{7}$, A. Rybowska ${ }^{8}$, D. Mirońska ${ }^{9}$, L. Rudnicki ${ }^{10}$, L. Piersiala ${ }^{11}$. These factors can be both objective and subjective in nature. The first group includes the testing of products, the rankings created by reputable institutions, etc., while the second group contains, for example, habits and customs. Undoubtedly, the decision involves some effort which is designed to meet a specific need and the elimination of some kind of discomfort. At the end of this process, satisfaction should appear, as a result of fulfilling the needs. For this reason, the client tries to do everything worth the effort to achieve the goal.

Buyers behave differently when purchasing common goods (e.g. routine purchases), and when buying a product worth a much larger part of their income. Regardless of what products the decision concerns, it may entail different behaviours, i.e. the buyer can passively accept the market offer, not devoting time to look for alternatives or he may actively seek the best offer, ignoring or thoroughly analysing marketing information from different companies. Such behaviours correspond to the idea of proactive personality proposed by Bateman and Crant ${ }^{12}$. In their opinion, the proactive personality is distinguished by: scanning the environment and identifying the opportunities for constructive change, showing initiative and taking action, and persevering until change is affected. In this context, attributes of such a personality correspond to the various actions of the buyers, e.g. intentional and unintentional, voluntary or compulsory behaviours ${ }^{13}$.

In addition, a closer look at the trends of behaviour described by $\mathrm{K}$. Liczmańska ${ }^{14}$, demonstrates the features that predestine purchase proactiveness, e.g.:

- consciousness (the consumers know their needs and expectations),

- seeking information (with a distance to advertisements),

\footnotetext{
${ }^{6}$ M. Miczyńska-Kowalska: Istota konsumpcji i zachowań konsumenckich - zarys problematyki. Annales Universitatis Mariae Curie-Skłodowska Lublin - Polonia. VOL. XXVI, 9, Sectio I, Wydział Filozofii i Socjologii UMCS, 2001.

${ }^{7}$ A. Falkowski, T. Tyszka: Psychologia zachowań konsumenckich. GWP, Gdańsk 2002.

8 A. Rybowska: Zachowania zakupowe klientów sklepów internetowych. Zeszyty Naukowe Akademii Morskiej w Gdyni, 65/2010.

${ }^{9}$ D. Mirońska: Zachowania nabywców na rynku - trendy i wpływ na działanie przedsiębiorstw. International Journal of Management and Economics, 27/2010, s. 114-132.

${ }^{10}$ L. Rudnicki: Zachowania konsumentów na rynku. PWE, Warszawa 2012.

${ }^{11}$ L. Piersiala: Strategie zakupowe konsumentów uwarunkowane płcią. Zeszyty Naukowe Politechniki Śląskiej. Seria: Organizacja i Zarządzanie, Z. 68 Nr Kol. 1905/2014.

${ }^{12}$ T. S. Bateman, J. M. Crant: The proactive component of organizational behavior: A measure and correlates. Journal of Organizational Behavior, 14/1993, p. 103-118;

13 A. Rybowska: Zachowania zakupowe klientów sklepów internetowych. Zeszyty Naukowe Akademii Morskiej w Gdyni, 65/2010, s. 24.

${ }^{14} \mathrm{~K}$. Liczmańska: Kluczowe czynniki determinujące zachowania konsumenckie na przykładzie mieszkańców województwa kujawsko-pomorskiego. Zeszyty Naukowe Uniwersytetu Szczecińskiego, nr 875 Problemy Zarządzania, Finansów i Marketingu, 41(2)/2015, s. 115-116.
} 
- $\quad$ expecting satisfaction (as the result of buying or using the product).

According to Bateman and Crant $^{15}$ proactive people show certain behaviours. In our opinion, these behaviours can also be related to shopping activities and scanning for change opportunities - the buyers themselves search for information about products, consider various options, estimate costs and choose the best and the conformable offer, and:

- $\quad$ set effective, change-oriented goals - proactive people are not guided only by commonly available information, they are looking for knowledge from various sources and confronting information, they go beyond the usual patterns, they constantly cross boundaries from the perspective of their own perception and other people ${ }^{16}$,

- $\quad$ anticipate and prevent problems - searching for possibilities of changes, e.g. in the case of unavailability of a product at a given point of sale, an alternative place of purchase has been prepared,

- do different things or do things differently - search-oriented attitude, no limitations, proactive people follow their own schemes, they are individualists, e.g. they move around the sales space in a different way than proposed by merchandising methods ${ }^{17}$,

- take action - proactive people are active observers, they take matters into their own hands,

- persevere - proactive people realize their goals, remain with their choices, however they can change their minds if circumstances require it,

- achieve results - implementation of decisions once made, activation of other people by influencing their attitudes, way of shopping, moving around the sales space.

In the buyer's mind, marketing messages shape the image of the product responding to their needs, which frees the customer from the necessity to look for alternatives. For some buyers, such messages are the most useful, desirable, saving time normally spent on searching for another product. Others would rather engage themselves in the search for alternative choices, devoting as much time to this activity as they consider necessary. Such behaviour of buyers corresponds to two of the six selection strategies presented by Falkowski and Tyszka ${ }^{18}$, i.e.:

- $\quad$ strategy of dominance and pseudo-dominance - selection of the best alternative, dominating over the other alternatives,

- $\quad$ and the strategy of the advantage of positive features - manifested in comparing the positive features of the products and then selecting the one that has more assumed features (there is no randomness, the choice is well-considered)

\footnotetext{
15 T. S. Bateman, J. M. Crant: Proactive behavior: meaning, impact, recommendations. Business Horizons, 42(3)/1999, p. 63-70

${ }^{16}$ A. Bańka: Intencjonalne konstruowanie przyszłości i wyprzedzające realizowanie celów: walidacja Skali Proaktywności Ogólnej. Czasopismo Psychologiczne. Psychological Journal, 21(1), 2015, s. 10.

17 G. Biesok, J. Wyród-Wróbel: Merchandising w łańcuchu dostaw. Wybrane Zagadnienia Logistyki Stosowanej,

Komitet Transportu Polskiej Akademii Nauk, 3/2006, s. 111-119.

${ }^{18}$ L. Piersiala: Strategie zakupowe konsumentów uwarunkowane płcią. Zeszyty Naukowe Politechniki Śląskiej. Seria: Organizacja i Zarządzanie, Z. 68 Nr Kol. 1905/2014, s. 95 za: A. Falkowski, T. Tyszka: Psychologia zachowań konsumenckich. GWP, Gdańsk 2002.
} 
Frequently such clients participate in the creation of marketing processes. For example, introducing certain innovations in the product or service, to better fulfil the needs and expectations of current and future customers ${ }^{19}$. A similar market activity is also prosumption, which can also be classified as a proactive consumer behaviour.

A. Bank ${ }^{20}$ points out that the proactive person takes causative action actively and subjectively, takes the initiative in improving current circumstances or creating new ones; involves challenging the status quo rather than passively adapting to present conditions $^{21}$. The concept of proactivity is similarly defined by Bateman and Crant ${ }^{22}$. According to the authors, being proactive means taking the initiative and changing things in the intended direction, for the better.

Being a proactive consumer means searching for information, confronting the knowledge coming from various sources, taking the initiative related to learning the market offer, possessing a resistance to marketing activities such as advertising, promotion at the point of sale, etc. This does not mean, however, that this kind of person always behaves in the same way in every situation, or that his purchase behaviour might sometimes show symptoms of proactivity and in other situations, might not. Regardless of criteria guiding the buyer or how much he will be proactive in his actions, his decisions have one goal - satisfaction with the choice. The proactivity in shopping behaviour can only be a factor supporting the satisfaction, which does not mean that it leads to satisfaction directly.

\section{Research methodology and data collection}

The main objective of the research was to verify whether proactive shopping behaviour declared by respondents has an influence on the relationship between expectations, perceived quality and customer satisfaction in a simple satisfaction model. The research concerned supermarket customers, and the used methods were: surveys and structural equations modelling methods (SEM).

The authors, based on a literature review, assumed ten behaviours which can manifest a proactive shopping attitude (Table 1). In the survey questionnaire, descriptions of these activities were formed as questions which respondents had to answer, assessing their behaviour in the 5-point Likert scale from absolutely disagree (1) to completely agree (5) with the neutral element: hard to say (3).

The first part of the questionnaire included assessment of purchasing behaviour and the general profile of the customer. In the second part, the respondents were able to evaluate 1,2 or 3 selected supermarkets, specifying the frequency of shopping, willingness to recommend this supermarket (according to the NPS methodology), opinion about the supermarket in 35 aspects (similarly on the Likert scale, identical to the one described above). One question was about the overall level of satisfaction (Generally, I am satisfied with shopping at this supermarket).

\footnotetext{
${ }^{19}$ A. I. Baruk: Prosumpcja jako wielowymiarowe zachowanie rynkowe. Zakres aktywności marketingowej współczesnych nabywców. PWE, Warszawa 2017, s. 23.

${ }^{20}$ A. Bańka, 2015, op. cit., s. 8.

${ }^{21}$ J. M. Crant: Proactive behavior in organizations. Journal of Management, 26(3)/2000, s. 436.

${ }^{22}$ T. S. Bateman, J. M. Crant, op. cit., 1999, s. 63.
} 
Table 1. Descriptions of proactive shopping behaviours used in the study

\begin{tabular}{ll}
\hline Code & Description \\
\hline A01 & I often buy products that improve my quality of life \\
\hline A02 & Consistently I try to buy products which I have imagined \\
\hline A03 & If I notice problems during shopping, I inform customer service \\
\hline A04 & I react to problems with the quality of goods (e.g. I make a complaint) \\
\hline A05 & If I need something or intend to buy something, I do it immediately \\
\hline A06 & I make purchase decisions quickly \\
\hline A07 & I always use the sales promotions/actions first \\
\hline A08 & Changes introduced in stores (e.g. changes in the location of goods) are not a problem for me \\
\hline A09 & I try to track price bargains \\
\hline A10 & I consult significant purchases with family and friends \\
\hline
\end{tabular}

Source: Authors' own research.

These statements were used as manifest variables in a simple satisfaction model. The model assumed that customer expectations remain in relation to the perceived quality and indirectly affect the satisfaction.

The selected model did not include the direct impact of expectations on satisfaction because in our previous studies we stated that there was no significant, direct impact of expectations on the satisfaction of supermarket customers ${ }^{23}$. The satisfaction model used for this study is presented in Figure 1.

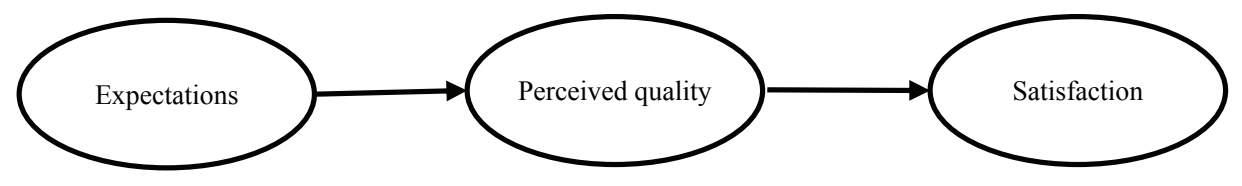

Figure 1. Satisfaction model used in the study

Source: Authors' own research.

We used structural equation modelling (SEM) methodology to verify the model. Assumptions of the modelling are presented in Table 2.

Table 2. Assumptions of constructed models

\begin{tabular}{ll}
\hline Modelling method & $\begin{array}{l}\text { Structural equations modelling (SEM) } \\
\text { Partial least squares method (PLS) }\end{array}$ \\
\hline Measuring manifest variables & $\begin{array}{l}\text { Survey research } \\
\text { 5-point Likert scale }\end{array}$ \\
\hline Latent variable blocks & Reflective \\
\hline Verification of the & Cronbach's $\alpha$ coefficient \\
measurement model & Dillon-Goldstein's $\rho$ coefficient \\
\hline Estimation & Bootstrap (100 subsamples) \\
& Intercept $=0$ in inner model equations \\
\hline Assessment of the moderation & Modelling in groups \\
effect & T-test on significance of the difference of the means in groups \\
& Coefficient of moderating effect $\mathrm{f}^{2}$ \\
\hline Calculations & PLSPM in R environment \\
\hline Source: Authors' own research. &
\end{tabular}

${ }^{23}$ G. Biesok, J. Wyród-Wróbel: Relacje pomiędzy postrzeganą jakością usług i satysfakcją klientów supermarketów. Problemy Jakości 50(5)/2018, s. 27-32. 
Survey questionnaires were distributed in southern Poland, in the Silesian and Lesser Poland voivodships, using a snowball method. After the formal and substantive control, 247 questionnaires were approved for further analysis. The basic characteristics of the surveyed population are presented in Table 2.

Table 2. Sample characteristics

\begin{tabular}{lllll}
\hline \multicolumn{1}{c}{ Feature } & & Percent & \multicolumn{1}{c}{ Supermarkets } & Percent \\
\hline Gender & female & $72,5 \%$ & Biedronka & $34,0 \%$ \\
\hline male & no data & $27,5 \%$ & Lidl & $17,4 \%$ \\
\hline & $1,7 \%$ & Tesco & $8,5 \%$ \\
\hline & less than 18 yr. & $0,8 \%$ & Kaufland & $8,1 \%$ \\
\hline & $18-25$ & $37,5 \%$ & Lewiatan & $6,5 \%$ \\
\hline & $25-40$ & $26,7 \%$ & Dino & $3,6 \%$ \\
\hline Voivodship & $40-65$ & $30,8 \%$ & Delikatesy Centrum & $3,6 \%$ \\
\hline & $65+$ & $2,5 \%$ & Other & $18,3 \%$ \\
\hline
\end{tabular}

Source: Authors' own research.

\section{Findings}

In the first step, a satisfaction model was determined on data from the whole sample (Figure 2). Assessment of the external (measurement) model gave satisfactory results all blocks of manifest variables showed sufficient internal consistency (Cronbach's $\alpha$ and Dillon-Goldstein's $\rho$ coefficients were higher than 0.7 - Table 3).

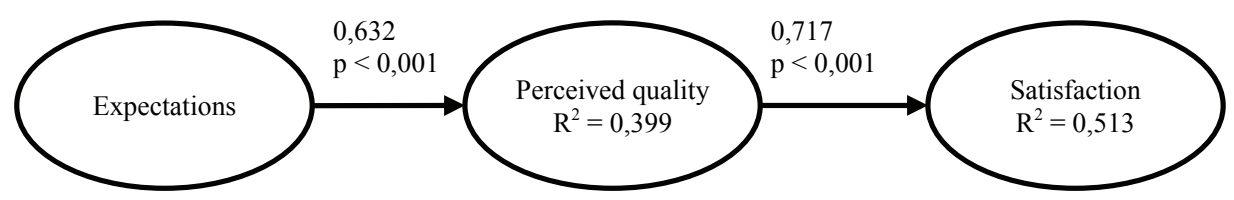

Figure 2. Satisfaction model determined on data from the whole sample Source: Authors' own research.

Table 3. Evaluation of the measurement model

\begin{tabular}{llll}
\hline Latent variable & $\begin{array}{l}\text { The number of } \\
\text { manifest variables }\end{array}$ & Cronbach's $\alpha$ & $\begin{array}{l}\text { Dillon-Goldstein's } \\
\rho\end{array}$ \\
\hline Expectations & 5 & 0.813 & 0.870 \\
\hline Perceived quality & 8 & 0.864 & 0.894 \\
\hline Satisfaction & 3 & 0.856 & 0.913 \\
\hline
\end{tabular}

Source: Authors' own research.

Next, the respondents were divided into two groups: those who positively responded to proactive aspect (I agree, I completely agree) and the others. These groups were named respectively: group $\mathrm{T}$ and group $\mathrm{N}$. The structure of respondents due to this division is shown in Figure 3.

We determined the model for each of these aspects and for each of these groups separately and examined the differences between the coefficients of the corresponding paths in the model. The significance of this difference was assessed using the t-test. The 
results are presented in Table 4. The significant differences were marked with an asterisk $\left.{ }^{*}\right)$ and with the value of significance threshold (p-values). The remaining differences are statistically insignificant.

A10 I consult significant purchases with family and

$$
\text { friends }
$$

A09 I try to track price bargains

A08 Changes introduced in stores (e.g. changes in the location of goods) are not a problem for me

A07 I always use the sales promotions/actions first

A06 I make purchase decisions quickly

A05 If I need something or intend to buy something,

$$
\text { I do it immediately }
$$

A04 I react to problems with the quality of goods

$$
\text { (e.g. I make a complaint) }
$$

A03 If I notice problems during the shopping, I inform the service

A02 Consistenly I try to buy products which I have imagined

A01 I often buy products that improve my quality of life

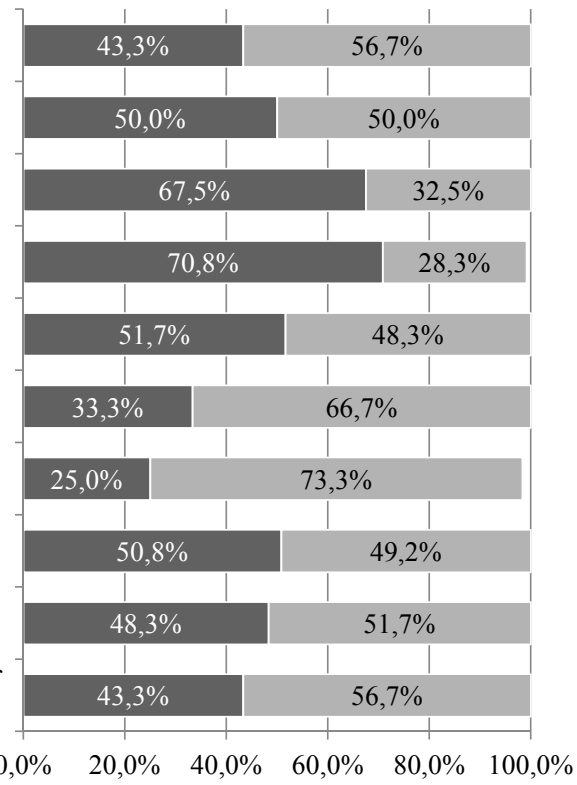

No and hard to say (group N) $\quad$ Rather yes and yes (group T)

Figure 3. The structure of the respondents due to the proactive behaviours Source: Authors' own research.

Table 4. Differences between the coefficients of the corresponding paths in the model

\begin{tabular}{ccccccc}
\hline Aspect & \multicolumn{2}{c}{$\begin{array}{c}\text { Expectations - Perceived quality } \\
\text { (path coefficients) }\end{array}$} & $\begin{array}{c}\text { Perceived quality - Satisfaction } \\
\text { (path coefficients) }\end{array}$ \\
\hline Group N & Group T & $\begin{array}{c}\text { Significance of } \\
\text { the difference }\end{array}$ & Group N & Group T & $\begin{array}{c}\text { Significance of } \\
\text { the difference }\end{array}$ \\
\hline A01 & 0.6424 & 0.6433 & 0.4945 & 0.6428 & 0.7824 & $\begin{array}{c}0.0399^{*} \\
\text { p }<0.05\end{array}$ \\
\hline A02 & 0.5945 & 0.5945 & 0.1775 & 0.6072 & 0.8095 & $0.0065^{*}$ \\
& & & & & 0.01 & 0.0928 \\
\hline A03 & 0.6559 & 0.6198 & 0.2596 & 0.7815 & 0.6813 & 0.1530 \\
\hline A04 & 0.5968 & 0.6519 & 0.4035 & 0.7780 & 0.7008 & $0.0281^{*}$ \\
\hline A05 & 0.7202 & 0.5849 & 0.0517 & 0.6327 & 0.7679 & 0.05 \\
\hline A06 & 0.6390 & 0.6189 & 0.3378 & 0.6704 & 0.7639 & 0.1088 \\
\hline A07 & 0.6401 & 0.6379 & 0.4714 & 0.6958 & 0.7794 & 0.3064 \\
\hline A08 & 0.6354 & 0.6516 & 0.4306 & 0.7008 & 0.7558 & 0.1988 \\
\hline A09 & 0.6171 & 0.6171 & 0.2798 & 0.6987 & 0.7541 & 0.0834 \\
\hline A10 & 0.7331 & 0.5513 & $0.0181^{*}$ & 0.7791 & 0.6773 & \\
\hline
\end{tabular}

Source: Authors' own research. 
In four cases, proactive behaviour exerts a moderating influence on the relationship between variables in the model. To assess the size of this moderation effect we used the $\mathrm{f}^{2}$ index calculated according to the formula:

$$
f^{2}=\frac{R_{\text {with moderator }}^{2}-R_{\text {without moderator }}^{2}}{1-R_{\text {with moderator }}^{2}}
$$

Where $\mathrm{R}^{2}$ is the coefficient of determination of the latent variable in the model. An absolute value $\mathrm{f}^{2}$ above 0.15 means moderate, and above 0.35 - a significant moderation effect. The results of calculations are presented in Table 5.

Table 5. Evaluation of moderating effects determined in the study

\begin{tabular}{lllllc}
\hline Aspect & $\begin{array}{l}\text { Latent } \\
\text { variable }\end{array}$ & $\begin{array}{l}\mathrm{R}^{2} \\
\text { Group N }\end{array}$ & $\begin{array}{l}\mathrm{R}^{2} \\
\text { Group T }\end{array}$ & $\mathrm{f}^{2}$ & Effect \\
\hline $\begin{array}{l}\text { A1 I often buy products that improve my } \\
\text { quality of life }\end{array}$ & Satisfaction & 0.413 & 0.612 & 0.51 & Significant \\
\hline $\begin{array}{l}\text { A2 Consistently I try to buy products } \\
\text { which I have imagined }\end{array}$ & Satisfaction & 0.369 & 0.656 & 0.83 & Significant \\
\hline $\begin{array}{l}\text { A5 If I need something or intend to buy } \\
\text { something, I do it immediately }\end{array}$ & Satisfaction & 0.400 & 0.590 & 0.46 & Significant \\
\hline $\begin{array}{l}\text { A10 I consult significant purchases with } \\
\text { family and friends }\end{array}$ & $\begin{array}{l}\text { Perceived } \\
\text { quality }\end{array}$ & 0.537 & 0.459 & -0.14 & $\begin{array}{l}\text { Moderate, } \\
\text { reverse }\end{array}$ \\
\hline
\end{tabular}

Source: Authors' own research.

\section{Summary and Conclusions}

In the conducted research we tried to answer the question of how proactive purchasing behaviour declared by the respondents influences the formation of customer satisfaction models. We used SEM methodology and the modelling in groups approach.

Despite using a wide set of 10 factors describing proactive shopping behaviour, only in four cases were significant differences detected. The satisfaction with purchases is determined by the perceived quality to a greater extent, in the case of customers declaring the following shopping behaviour:

- frequent buying of products that improve the standard of living,

- the consistency in purchasing perceived products,

- quickness (urgency) in purchasing decisions.

In addition, consultation of family or friends in important purchases has a reverse moderating effect. In the group of people declaring such behaviour, the perceived quality of supermarket services is less determined by customer expectations.

We can conclude that for customers demonstrating some proactive shopping behaviour, perceived quality is the main factor of satisfaction with purchases that were made.

An important problem of our modelling is the unsatisfactory model fit. We used the GoF (goodness of fit) to assess model fit and in individual cases it reached values in the range of 0.5-0.6 (when preferred values are at least above 0.7). This means that research conclusions should be taken with caution, treated as preliminary and verified in future studies. 
In future research it would be necessary to take into account other factors than those described in the publication and to verify their impact on the relations between variables in the model. One can also consider a quantitative description of some proactive factors (e.g. using data on the frequency of purchases, time spent on purchases, etc.).

Further research on proactive shopping attitudes and their impact on customer satisfaction, creating a profile of clients characterized by proactive shopping behaviour, would also have practical implications - it would allow better matching of the product offer, sales space including product displays and the offer of commercial services to the needs of proactive people.

\section{Bibliography}

Bańka A.: Intencjonalne konstruowanie przyszłości i wyprzedzające realizowanie celów: walidacja Skali Proaktywności Ogólnej. Czasopismo Psychologiczne. Psychological Journal, 21(1)/2015.

Baruk A. I.: Prosumpcja jako wielowymiarowe zachowanie rynkowe. Zakres aktywności marketingowej współczesnych nabywców, PWE, Warszawa 2017.

Bateman T. S., Crant J. M.: The proactive component of organizational behavior: A measure and correlates, Journal Of Organizational Behavior 14/1993.

Bateman T. S., Crant J. M.: Proactive behavior: meaning, impact, recommendations, Business Horizons 42(3)/1999.

Biesok G., Wyród-Wróbel J.: Modele satysfakcji klienta, Difin, Warszawa 2016.

Biesok G., Wyród-Wróbel J.: Relacje pomiędzy postrzeganą jakością usług i satysfakcją klientów supermarketów, Problemy Jakości 50(5)/2018.

Biesok G., Wyród-Wróbel J.: Merchandising w łańcuchu dostaw, Wybrane Zagadnienia Logistyki Stosowanej, Komitet Transportu Polskiej Akademii Nauk, 3/2006.

Claes R., Loo K. V.: Relationships of proactive behaviour with job-related affective well-being and anticipated retirement age: an exploration among older employees in Belgium, European Journal of Ageing 8(4)/2011.

Crant J. M.: Proactive behavior in organizations, Journal of Management 26(3)/2000.

Falkowski A., Tyszka T.: Psychologia zachowań konsumenckich, GWP, Gdańsk 2002.

Ismail A., Nowalid W. A. W. M. and Bakar R. A.: Proactive behaviour as a mediator of the relationship between career management andcareer satisfaction, Jurnal Pengurusan (UKM Journal of Management) 48/2016.

Liczmańska K.: Kluczowe czynniki determinujące zachowania konsumenckie na przykładzie mieszkańców województwa kujawsko-pomorskiego, Zeszyty Naukowe Uniwersytetu Szczecińskiego, nr 875 Problemy Zarządzania, Finansów i Marketingu 41(2)/2015.

Ling N-P., Bandar N. F. A., Halim F. A. and Muda A. L.: Proactive behaviour as a mediator in the relationship between quality of work life and career success, International Journal of Business and Society 18 S4/2017.

Mallin M. L., Ragland Ch. B. and T. A. Finkle: The Proactive Behavior of Younger Salespeople: Antecedents and Outcomes, Journal of Marketing Channels 21/2014.

Miczyńska-Kowalska M.: Istota konsumpcji i zachowań konsumenckich - zarys problematyki, Annales Universitatis Mariae Curie-Skłodowska Lublin - Polonia, . Vol. XXVI, 9, Sectio I 2001.

Mirońska D.: Zachowania nabywców na rynku - trendy i wpływ na działanie przedsiębiorstw, International Journal of Management and Economics 27/2010.

Piersiala L.: Strategie zakupowe konsumentów uwarunkowane płcią, Zeszyty Naukowe Politechniki Śląskiej, Seria: Organizacja i Zarządzanie 68(1905)/2014.

Rudnicki L.: Zachowania konsumentów na rynku, PWE, Warszawa 2012. 
Rybowska A.: Zachowania zakupowe klientów sklepów internetowych, Zeszyty Naukowe Akademii Morskiej w Gdyni nr 65, grudzień 2010.

Wu Ch. H., Parker S. K.: Thinking and Acting in Anticipation: A Review of Research on Proactive Behavior, Advances in Psychological Science 21(4)/2013.

\section{Proaktywne zachowania zakupowe i ich relacje w prostym modelu satysfakcji}

\section{Streszczenie}

Celem przeprowadzonych badań była chęć weryfikacji czy i w jakim stopniu deklarowane przez respondentów proaktywne zachowania zakupowe wpływają na relacje między oczekiwaniami, postrzeganą jakością a satysfakcją klientów w prostym modelu satysfakcji. Podmiotem badań byli klienci supermarketów.

Autorzy artykułu przyjęli dziesięć zachowań, w których może demonstrować się proaktywna postawa zakupowa. Następnie ustalono modele satysfakcji w grupach respondentów deklarujących lub niedeklarujących dane zachowanie. Głównymi wnioskami wynikającym z analiz jest to, że satysfakcja $\mathrm{z}$ zakupów w większym stopniu zdeterminowana jest przez postrzeganą jakość w przypadku klientów deklarujących częste kupowanie produktów, które poprawiają poziom życia, konsekwencję w nabywaniu upatrzonych produktów oraz szybkość (niezwłoczność) podejmowanych decyzji zakupowych.

Słowa kluczowe: badania konsumenckie, proaktywne zachowania zakupowe, model satysfakcji, modelowanie równań strukturalnych (SEM)

JEL Codes: M310, L810

Information about authors

PhD. Eng. Grzegorz Biesok

University of Bielsko-Biała

Wydział Zarządzania i Transportu, Katedra Zarzadzania,

43-309 Bielsko-Biała, ul. Willowa 2.

e-mail: gbiesok@ath.eu

ORCID: 0000-0002-4987-5823

PhD. Eng. Jolanta Wyród-Wróbel

University of Bielsko-Biała

Wydział Zarządzania i Transportu, Katedra Zarzadzania,

43-309 Bielsko-Biała, ul. Willowa 2.

e-mail: jwyrod@ath.bielsko.pl

ORCID: 0000-0001-6018-9755 